\title{
Microbial biomass, nutrient availability and nutrient uptake by wheat in two soils with organic amendments
}

\author{
M.A. Malik ${ }^{1}$, K.S. Khan ${ }^{1}$, P. Marschner ${ }^{2 *}$, Fayyaz-ul-Hassan ${ }^{3}$ \\ ${ }^{1}$ Department of Soil Science \& Soil and Water Conservation, PMAS Arid Agriculture University Rawalpindi, Pakistan. ${ }^{2}$ School of \\ Agriculture, Food and Wine, The Waite Research Institute, The University of Adelaide, Adelaide, SA 5005, Australia. ${ }^{3}$ Department \\ of Agronomy, PMAS-Arid Agriculture University Rawalpindi, Pakistan. *Corresponding author: petra.marschner@adelaide.edu.
}

\begin{abstract}
A 72-day greenhouse pot experiment was conducted with a sandy loam or a silt loam soil to examine the effects of farmyard manure (FYM), poultry litter (PL) and biogenic waste compost (BWC) at $10 \mathrm{~g} \mathrm{dw} \mathrm{kg}^{-1}$ soil on microbial biomass and activity and growth and nutrient uptake by wheat. Soil samples were collected at days $0,14,28,42$, 56 and 72 after planting. Growth and nutrient uptake by wheat were determined on day 72 . All three amendments increased microbial biomass $\mathrm{C}, \mathrm{N}$ and $\mathrm{P}$, dehydrogenase activity, plant growth and nutrient uptake with a greater effect by FYM and PL than by BWC. All amendments increased microbial biomass C, N and P and enzyme activity particularly on day 0 . These microbial parameters decreased after day 0 indicating microbial biomass turnover. All amendments increased plant growth and nutrient uptake. It is concluded that organicamendments can stimulate microbial growth and nutrient uptake as well as plant growth and nutrient uptake. Microbes can increase plant nutrient availability by nutrient mobilisation but also because nutrients taken up by the microbial biomass initially could become available to plants when the microbial biomass turns over as the easily available $\mathrm{C}$ is depleted.
\end{abstract}

Keywords: Compost, enzyme activity, farmyard manure, microbial biomass, poultry litter, nutrient uptake

\section{Introduction}

Soils in semi-arid regions are often low in organic matter content $(<1 \%)$ and deficient in plantavailable nutrients, especially $\mathrm{P}$ despite having high total P content (Muhammad et al., 2008). The low $\mathrm{P}$ availability is caused by formation of insoluble $\mathrm{P}$ salts such as $\mathrm{Ca}$ or $\mathrm{Fe} / \mathrm{Al}$ phosphates and by sorption of $P$ to soil particles. Due to the low rainfall,the use of chemical fertilizers to satisfy nutrient requirements of plants is often ineffective, because of in adequate moisture for mass flow and diffusion. Thus, nutrient storage in the soil microbial biomass and later its release to plants through microbial turnover may be important processes for successful crop production in such areas (Khan and Joergensen, 2006). Use of organic materials including crop residues, manures, composts and other rural and urban biogenic waste has been suggested to 
enhance soil nutrient bioavailability and to increase fertiliser use efficiency (Gichangi et al., 2009; Takeda et al., 2009). However, the effect of the organic amendments on nutrient availability depends on their decomposability and nutrient concentration (Singh and Jones, 1976; Reddy et al., 2005).

Microbial activity affects soil nutrient availability after the addition of organic materials (Gichangi et al., 2009; Khan and Joergensen, 2009). When carbon availability is high, uptake of macronutrients such as $\mathrm{N}$ and $\mathrm{P}$ by the microbial biomass is high. Under these circumstances the microbial biomass can compete with plants for nutrients. On the other hand, microbial P uptake can prevent $\mathrm{P}$ fixation by soil colloids (Ayaga et al., 2006; Gichangi et al., 2009; Khan and Joergensen, 2009) or leaching of N. Microbial biomass N and P become availableto plants upon microbial turnover when the easily available C is depleted (Gichangi et al., 2009; Malik et al., 2012). Thus microbes can be considered as slow release fertilisers that store nutrients (mainly $\mathrm{N}$ and P) when nutrient concentrations are high and then release them (Ryazanova et al., 2009; Docampo et al., 2010).

Therefore, for better nutrient management it is important to understand nutrient dynamics in response to organic amendments and the relationship between nutrient uptake by plants and the microbial biomass. The first aim of this study was to evaluate the effects of three organic amendments (farmyard manure, poultry litter and biogenic waste compost) on microbial biomass and activity(dehydrogenase activity) and available $\mathrm{P}$ (Olsen P) over a 72-day period as well as wheat growth and nutrient uptake in two P deficient alkaline soils of different texture. The second aim was to evaluate the relationship between microbial parameters and nutrient availability to wheat.

\section{Material and Methods}

\subsection{Experimental setup}

A greenhouse pot experiment was conducted with wheat using two $\mathrm{P}$ deficient soils from Potohar,
Pakistan: Balkassar (sandy loam, Haplargids, latitude $32^{\circ} 55.377^{\prime} \mathrm{N}$, longitude $072^{\circ} 45.398^{\prime} \mathrm{E}$, elevation 507 $\mathrm{m}$ ) and Qutbal (silt loam, Ustorthents, latitude $33^{\circ}$ $35.868^{\prime} \mathrm{N}$, longitude $072^{\circ} 48.621^{\prime} \mathrm{E}$, elevation $529 \mathrm{~m}$ ) which represent typical semi-arid agricultural soils in this region (Table 1).

Surface soil samples $(0-15 \mathrm{~cm})$ were collected and visible plant debris, soil animals and stones were manually removed from the field moist soil samples. Then the remaining soil was thoroughly mixed. A portion of each soil was air-dried at room temperature, ground and passed through a 2-mm sieve for analysis of various physical (particle size distribution, water holding capacity and moisture content) and chemical $\left(\mathrm{pH}, \mathrm{EC}, \mathrm{CaCO}_{3}, \mathrm{CEC}\right.$, organic $\mathrm{C}$, Olsen $\mathrm{P}$, total $\mathrm{N}, \mathrm{P}, \mathrm{K}, \mathrm{Ca}$ and $\mathrm{Mg}$ ) properties. The three organic amendments: i) farmyard manure (FYM), ii) poultry litter (PL) and iii) biogenic waste compost (BWC) were applied at the rate of $10 \mathrm{~g} \mathrm{~kg}^{-1}$ soil (oven dry basis). This rate corresponds to $20 \mathrm{Mg} \mathrm{dw} \mathrm{ha}^{-1}$ which is a common application rate in Pakistan. Because of the local supply, FYM and PL are used as soil amendments by farmers whereas BWC is rarely used at present. However with the increase urbanization, the supply of BWC will increase and may be used by farmers close to the composting facility. The amendments were thoroughly mixed with the soils. The FYM and PL were obtained from local farms, whereas the BWC prepared from biogenic household waste was collected from a compost plant in Lahore (Pakistan). Un-amended soils were used as controls and mixed similarly. There were four replicates per treatment and soil ( 32 pots in total). The soil moisture content was adjusted to $50 \%$ WHC gravimetrically by adding deionised water. The soil was filled into pots $(0.5 \mathrm{~kg}$ pot ${ }^{-1}$ ) and five seeds of wheat (Triticuma estivum L. cultivar GA-2002) were sown in each pot two weeks after the addition of organic amendments. This planting time was chosen to allow microbial biomass turnover and because organic amendments are often applied several weeks before sowing in the semi- arid region of Pakistan. After germination, the plants were thinned to 3 seedlings per pot. 
Table 1. Physico-chemical properties of Balkassar and Qutbal soils $(n=4)$.

\begin{tabular}{|c|c|c|}
\hline Property & Balkassar & Qutbal \\
\hline Classification & Haplargids & Ustorthents \\
\hline Texture & Sandy loam & Silt loam \\
\hline Sand (\%) & 65.1 & 11.9 \\
\hline Silt (\%) & 22.3 & 62.0 \\
\hline Clay (\%) & 12.6 & 26.1 \\
\hline WHC (\%) & 24 & 29 \\
\hline $\mathrm{pH}_{1: 2.5}$ & 8.1 & 8.2 \\
\hline $\mathrm{EC}_{1: 2.5}\left(\mathrm{dS} \mathrm{m}^{-1}\right)$ & 0.13 & 0.12 \\
\hline $\mathrm{CaCO}_{3}(\%)$ & 9.0 & 17.8 \\
\hline CEC $\left(\mathrm{cmol} \mathrm{kg}^{-1}\right)$ & 12.7 & 15.6 \\
\hline Organic $C\left(\mathrm{~g} \mathrm{~kg}^{-1}\right)$ & 2.8 & 3.9 \\
\hline Total N ( g kg $^{-1}$ ) & 0.3 & 0.5 \\
\hline Total P $\left(\mu g g^{-1}\right)$ & 560 & 608 \\
\hline Olsen P $\left(\mu g g^{-1}\right)$ & 2.7 & 2.0 \\
\hline Total K ( $\left.\mathrm{g} \mathrm{kg}^{-1}\right)$ & 12.0 & 15.5 \\
\hline Total Ca $\left(\mathrm{g} \mathrm{kg}^{-1}\right)$ & 6.2 & 24.4 \\
\hline Total Mg $\left(\mathrm{g} \mathrm{kg}^{-1}\right)$ & 11.3 & 10.4 \\
\hline $\mathrm{C} / \mathrm{N}$ ratio & 9.3 & 7.8 \\
\hline
\end{tabular}


Water was regularly added to the pots to maintain the water content at $50 \%$ WHC. Soil samples (60 gram oven dry weight equivalent) were removed by coring on days $0,14,28,42,56$ and 72 after the sowing of seeds for determination of microbial biomass $\mathrm{C}, \mathrm{N}$, $\mathrm{P}$ and dehydrogenase activity and Olsen P. The soil samples were stored at $-15{ }^{\circ} \mathrm{C}$ prior to analysis. The wheat plants were harvested on day 72 . Roots of plants from each pot were extracted from the soil and washed. The shoots were cut off at the soil surface, washed, dried at $65^{\circ} \mathrm{C}$, ground and analysed for macro nutrient $(\mathrm{N}, \mathrm{P}, \mathrm{K}, \mathrm{Ca}$ and $\mathrm{Mg}$ ) concentrations. The nutrient uptake per plant was calculated by multiplying nutrient concentration by shoot dry weight.

\subsection{Analysis of organic amendments}

The $\mathrm{pH}$ and $\mathrm{EC}$ of the organic materials were measured in a 1:2 solid: water ratio (Peters et al., 2003). Total organic $\mathrm{C}$ was determined by the WalkleyBlack method (Nelson and Sommers, 1982). For the determination of total $\mathrm{N}$ and total $\mathrm{P}$, the organic material was digested in a $1.2: 1 \mathrm{H}_{2} \mathrm{SO}_{4}: \mathrm{H}_{2} \mathrm{O}_{2}$ mixture at $360{ }^{\circ} \mathrm{C}$ after which total $\mathrm{N}$ and $\mathrm{P}$ were measured colorimetrically (Anderson and Ingram, 1993). Total $\mathrm{Ca}$ and $\mathrm{Mg}$ were determined by AAS after digestion with 2:1 $\mathrm{HNO}_{3}: \mathrm{HClO}_{4}$ mixture (Ryan et al., 2001).

\subsection{Soil analysis}

Particle size distribution was determined by the hydrometer method (Gee and Bauder, 1986). Water holding capacity was measured by preparing a saturated soil paste (Anderson and Ingram, 1993). Soil $\mathrm{pH}$ and EC were determined in a 1:2.5 (w/v) soil water ratio (Anderson and Ingram, 1993). Organic C was determined by the dichromate digestion method (Nelson and Sommers, 1982). Plant available P (Olsen $\mathrm{P}$ ) was measured by extracting soil with $0.5 \mathrm{M}$ $\mathrm{NaHCO}_{3}$ at $\mathrm{pH} 8.5$ (Olsen and Sommers, 1982). The $\mathrm{H}_{2} \mathrm{SO}_{4}-\mathrm{H}_{2} \mathrm{O}_{2}$ digestion method as described above for the organic amendments was used to extract total $\mathrm{P}$ from the soils. The P concentration was measured colorimetrically (Murphy and Riley, 1962).
Total $\mathrm{Ca}$ and $\mathrm{Mg}$ were determined by AAS after digestion with 2:1 $\mathrm{HNO}_{3}: \mathrm{HClO}_{4}$ mixture (Ryan et al., 2001).

For microbial analyses, the soil samples stored at $-15^{\circ} \mathrm{C}$ were taken out of the freezer and equilibrated to room temperature. Microbial biomass $\mathrm{C}, \mathrm{N}$ and $\mathrm{P}$ were determined by the fumigation-extraction method (Brookes et al., 1982; Brookes et al., 1985; Vance et al., 1987; Joergensen et al.,1995). The organic C in the soil extracts was measured using an automated total organic $\mathrm{C}$ (TOC) analyzer; microbial biomass $\mathrm{C}$ was calculated by using a $k_{E C}$ value of 0.45 (Wu et al., 1990). The total $\mathrm{N}$ in soil extracts was measured after Kjeldahl digestion and microbial biomass $\mathrm{N}$ was calculated by using a $k_{E N}$ value of 0.54 (Brookes et al., 1985). The $\mathrm{P}$ concentration was determined colorimetrically and the microbial biomass $\mathrm{P}$ was calculated by using a $k_{E P}$ value of 0.40 (Brookes et al., 1982). Dehydrogenase activity was measured by the reduction of 2, 3, 5-triphenyltetrazolium chloride (TTC) in triphenylformazan (TPF) (Alef, 1995).

\subsection{Plant analysis}

Total $\mathrm{N}$ and Pin the plant samples were measured after $\mathrm{H}_{2} \mathrm{SO}_{4}-\mathrm{H}_{2} \mathrm{O}_{2}$ digestion as described above for the organic amendments. After digestion with 2:1 $\mathrm{HNO}_{3}: \mathrm{HClO}_{4}$ mixture (Ryan et al., 2001), total $\mathrm{Ca}$ and $\mathrm{Mg}$ were determined by AAS and K was measured by flame photometer (Ryan et al., 2001).

\subsection{Statistical analysis}

The concentrations of the microbial biomass $\mathrm{C}, \mathrm{N}$ and $\mathrm{P}$ and dehydrogenase activity at a given sampling time and of plant parameters at harvest were compared by 2-way ANOVA (soils $\times$ organic amendment) and their means were compared by using Tukey HSD test at $5 \%$ probability level using the software Statistix 8.1. Only significant differences $(p \leq 0.05)$ are mentioned in the text. 


\section{Results}

\subsection{Soil properties}

The two soils, Balkassar (sandy loam, Haplargids) and Qutbal (silt loam, Ustorthents) developed from sandstone and loess parent materials, respectively (Table 1). The Balkassar soil had higher sand content but lower contents of clay and silt than the Qutbal soil. Both soils were alkaline and low in available $\mathrm{P}$ (less than $3 \mu \mathrm{g}$ available $\mathrm{P} \mathrm{g}^{-1}$ soil) Compared to Balkassar soil, the Qutbal soil had higher concentrations of total organic $\mathrm{C}, \mathrm{Ca}$ and $\mathrm{N}$.

\subsection{Composition of organic materials}

Compared to the other organic amendments, $\mathrm{PL}$ had the highest total organic $\mathrm{C}$ and total $\mathrm{P}$ concentrations and the highest $\mathrm{C} / \mathrm{N}$ ratio (Table 2). Farmyard manure had the highest concentrations of $\mathrm{Ca}$ and the lowest $\mathrm{pH}$ and $\mathrm{EC}$. The BWC had the highest $\mathrm{pH}, \mathrm{EC}$ and trace element concentrations, but the lowest total $\mathrm{C}$ and $\mathrm{N}$ concentrations.

Table 2. Composition of farmyard manure, poultry litter and biogenic waste compost $(n=4)$.

\begin{tabular}{lccc}
\hline Properties & $\begin{array}{c}\text { Farmyard } \\
\text { manure }\end{array}$ & Poultry litter & $\begin{array}{c}\text { Biogenic waste } \\
\text { compost }\end{array}$ \\
\hline $\mathrm{pH}_{1: 2}$ & 6.8 & 7.3 & 7.8 \\
$\mathrm{EC}_{1: 2}\left(\mathrm{dS} \mathrm{m}^{-1}\right)$ & 7.8 & 14.9 & 15.3 \\
$\mathrm{TOC}\left(\mathrm{g} \mathrm{kg}^{-1}\right)$ & 112.3 & 143.0 & 67.8 \\
Total N $\left(\mathrm{g} \mathrm{kg}^{-1}\right)$ & 8.6 & 8.7 & 5.6 \\
Total P $\left(\mathrm{g} \mathrm{kg}^{-1}\right)$ & 4.0 & 5.1 & 2.6 \\
Total K $\left(\mathrm{g} \mathrm{kg}^{-1}\right)$ & 8.4 & 11.0 & 11.5 \\
$\mathrm{Ca}\left(\mathrm{g} \mathrm{kg}^{-1}\right)$ & 76.7 & 33.9 & 37.7 \\
$\mathrm{Mg}\left(\mathrm{g} \mathrm{kg}^{-1}\right)$ & 9.0 & 10.1 & 8.0 \\
Fe $\left(\mathrm{g} \mathrm{kg}^{-1}\right)$ & 5.9 & 5.0 & 14.0 \\
$\mathrm{Mn}\left(\mathrm{mg} \mathrm{kg}^{-1}\right)$ & 320.6 & 333.7 & 405.4 \\
$\mathrm{Zn}\left(\mathrm{mg} \mathrm{kg}^{-1}\right)$ & 91.0 & 119.4 & 361.7 \\
$\mathrm{Cu}\left(\mathrm{mg} \mathrm{kg}^{-1}\right)$ & 27.1 & 25.7 & 245.0 \\
Total C/ N & 13.1 & 16.4 & 12.1 \\
Total C/ P & 27.9 & 28.0 & 25.8 \\
\hline & & & \\
\hline
\end{tabular}




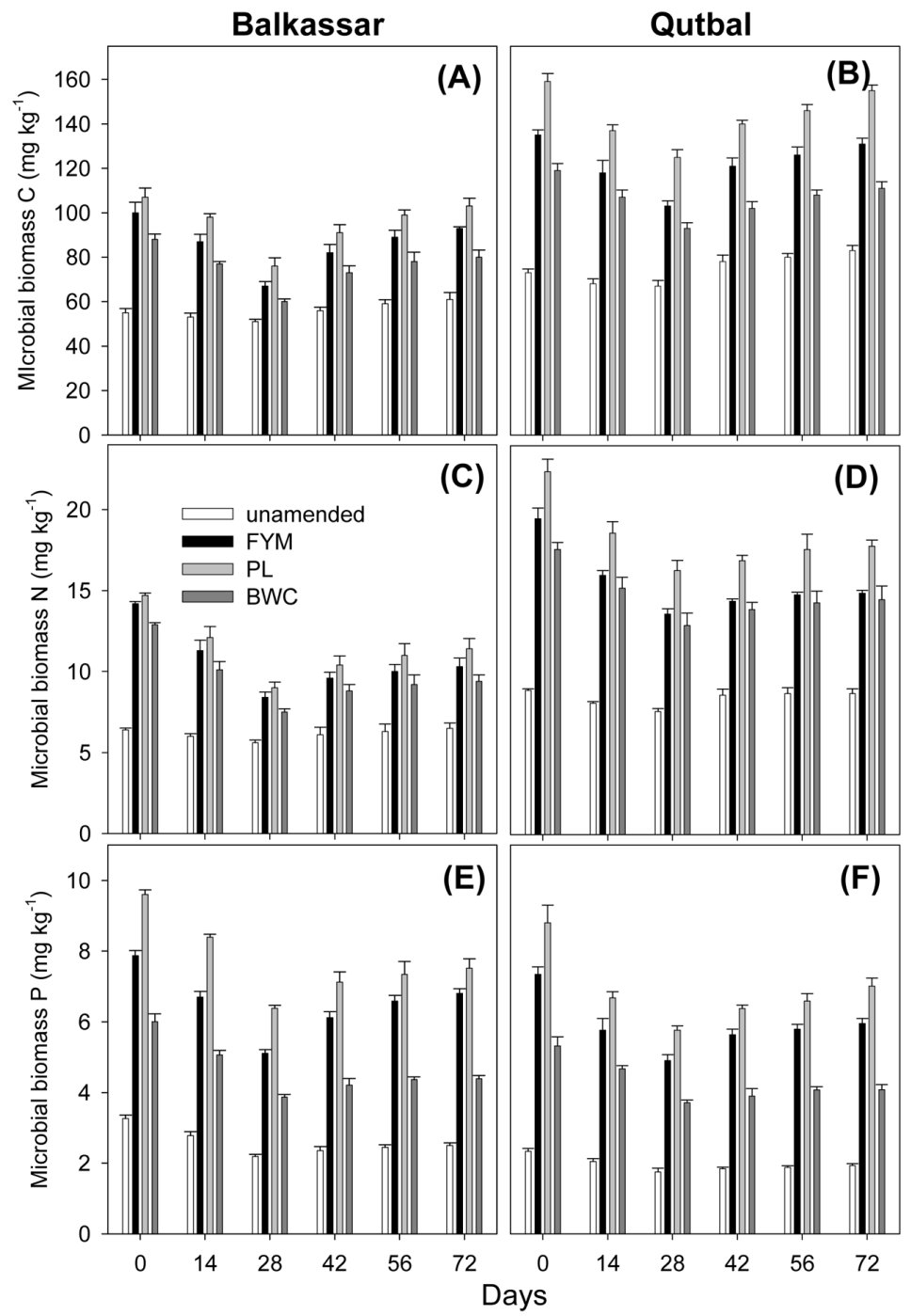

Figure 1. Microbial biomass C (A, B), N (C, D) and P (E, F) on days 1, 14, 28, 42, 56 and 72 in Balkassar (A, C, E) and Qutbal soil (B, D, F) unamended or amended with farmyard manure (FYM), poultry litter (PL) or biogenic waste compost (BWC) ( $\mathrm{n}=4$, vertical lines show standard deviation of data). 


\subsection{Microbial biomass and activity}

Microbial biomass $\mathrm{C}$ and $\mathrm{N}$ concentrations were $43 \%$ and $50 \%$ higher in Qutbal than in Balkassar soil, whereas the microbial biomass $\mathrm{P}$ concentration was $13 \%$ greater in Balkassar soil (Figure 1). Application of organic amendments significantly increased microbial biomass $\mathrm{C}, \mathrm{N}$ and $\mathrm{P}$ concentrations compared to the unamended soil in both soils with the smallest increases in microbial C (40-83\%) and the greatest in microbial P (96-220\%). Amendment with PL induced the greatest increase, BWC the least. The differences in $\mathrm{MBC}$ and $\mathrm{MBN}$ concentrations among amendments were greater in Qutbal than in Balkassar soil. Over the time, the all three biomass indices showed a similar pattern. High $\mathrm{MBC}, \mathrm{MBN}$ and $\mathrm{MBP}$ concentrations occurred on day 0 , then declined to day 28 after which they increased again to day 72 to similar values as on day 0 .

Dehydrogenase activity was significantly higher in Qutbal than in Balkassar soil and was increased by the addition of PL whereas addition of FYM and BWChad no significant effect (Figure 3 ). In both soils and all treatments, dehydrogenase decreased over time, particularly in the first 28 days, with greater decreases in Qutbal than in Balkassar soil.

\subsection{Phosphorus availability}

In the unamended soil and that amended with FYM and PL, the available $\mathrm{P}$ (Olsen P) concentrationon day 0 was significantly higher in Balkassar soil than in Qutbal soil (Figure 2). Addition of PL and FYM increased the available $P$ concentrations 6-fold whereas BWC increased the concentrations only 3 -fold. The available $\mathrm{P}$ concentrations remained high during the first 28 days but then declined.

\subsection{Wheat growth and nutrient uptake}

In the unamended controls, shoot and root dry weight were higher in Balkassar than in Qutbal soil but there was little difference in dry weight in the amended soils
(Table 3). The organic amendments increased shoot and root dry weight in both soils with the strongest increase in shoot dry weight by FYM and the smallest by BWC. FYM and PL stimulated root dry weight to a similar extent. The amendments also increased the number of tillers per plant; the effect of FYM and PL was greater than that of BWC (Table 3). Wheat grown in Balkassar soil had $11 \%$ to $17 \%$ higher $\mathrm{N}, \mathrm{P}$ and $\mathrm{K}$ concentrations than that grown in the Qutbal soil (Figure 3). However, the shoot concentrations of $\mathrm{Ca}$ and $\mathrm{Mg}$ were $34 \%$ and $93 \%$ greater in Qutbal soil. Compared to the unamended control, application of FYM decreased shoot $\mathrm{N}$ concentration. The shoot $\mathrm{P}$ concentration was highest with PL whereas the $\mathrm{K}$ concentration was highest with BWC. All amendments decreased shoot $\mathrm{Ca}$ concentrations and had little effect on shoot $\mathrm{Mg}$ concentrations.

The uptake of N, P and K by wheat was $35 \%$ to $54 \%$ higher in Balkassar than in Qutbal soil whereas the uptake of $\mathrm{Ca}$ and $\mathrm{Mg}$ was $6 \%$ and $41 \%$ greater in Qutbal than Balkassar soil (Figure 3). The uptake of all measured macronutrients was significantly enhanced by the organic amendments in both soils with greatest increases by PL and least by BWC.

\section{Discussion}

This study showed that organic amendments can supply nutrients to soil microbes and also to plants. The addition of organic carbon with the amendments stimulated microbial growth and activity thus mineralisation of organic $\mathrm{N}$ and $\mathrm{P}$ in the amendments. Although microbes and plants may initially compete for nutrients, the amendments supplied sufficient nutrients for plants and microbes, particularly FYM and PL which had higher nutrient concentrations than BWC. Further, microbial biomass turnover could release nutrients for plant uptake when the readily available organic $\mathrm{C}$ from the amendments is depleted. 

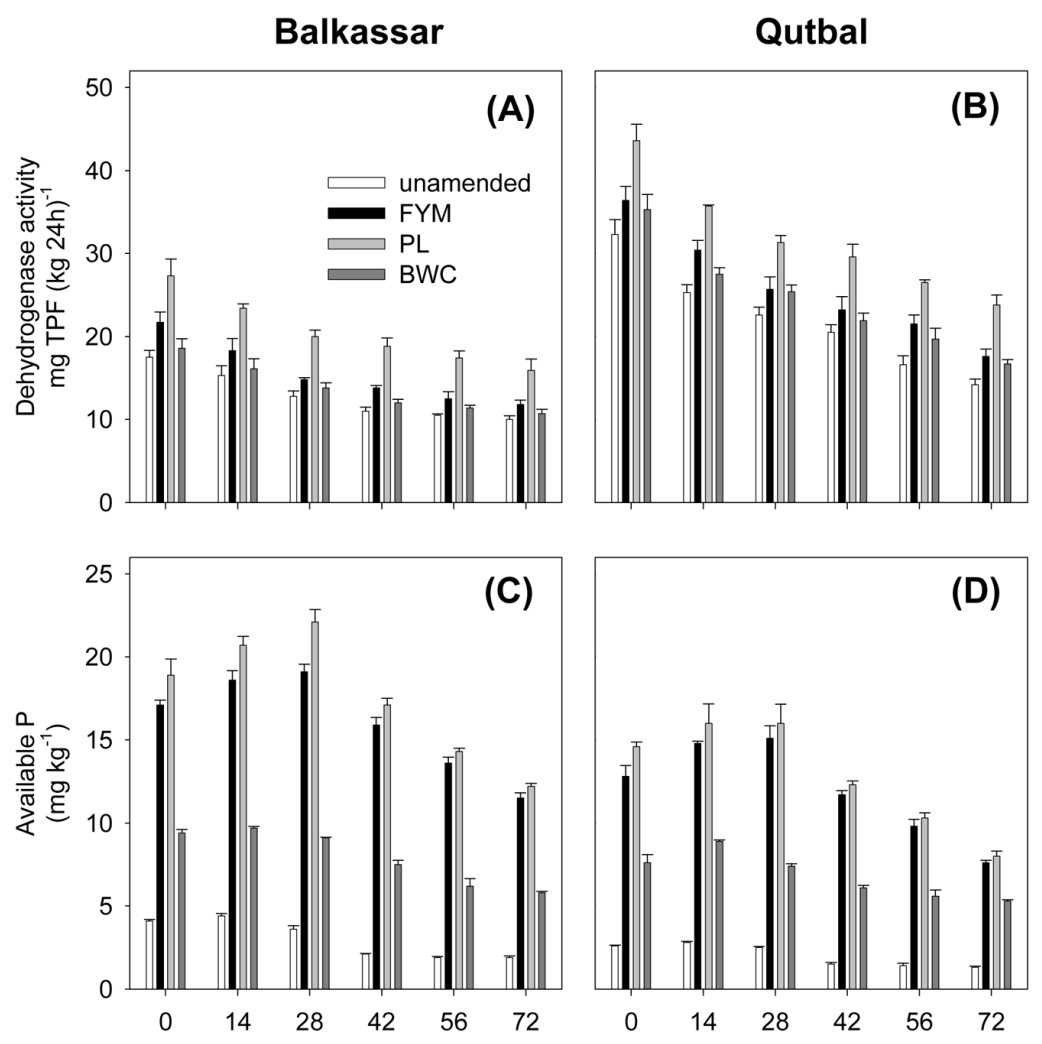

Figure 2. Dehydrogenase activity (A, B) and available P (Olsen P) (C, D) on days 1, 14, 28, 42, 56 and 72 in Balkassar (A, C) and Qutbal soil (B, D) unamended or amended with farmyard manure (FYM), poultry litter (PL) or biogenic waste compost (BWC) ( $\mathrm{n}=4$,vertical lines show standard deviation of data).

\subsection{Organic amendments}

FYM and PL had a greater effect on microbial activity and biomass $\mathrm{C}, \mathrm{N}$ and $\mathrm{P}$ as well as on plant growth and nutrient uptake than BWC. This can be explained by the higher nutrient concentrations (TOC, TN and TP) in the former. Addition of both FYM and PL resulted in an increase in microbial biomass $\mathrm{C}, \mathrm{N}$ and $\mathrm{P}$ with a greater increase with PL which can be explained by its higher TOC concentration. Despite the increase in microbial nutrient uptake, FYM and PL also stimulated plant growth and N, P and K uptake. Thus they supplied enough nutrients to satisfy microbial and plant demand.

The amendment with BWC also increased nutrient uptake by microbes and plants but to a lesser extent than the other two amendments. This can be explained by the lower nutrient concentrations in BWC compared to FYM and PL and by the poorer decomposability of the organic material in the compost. The available organic material will already have been decomposed during the composting processes, thus only the more recalcitrant compounds were left (Wang et al., 2004). 

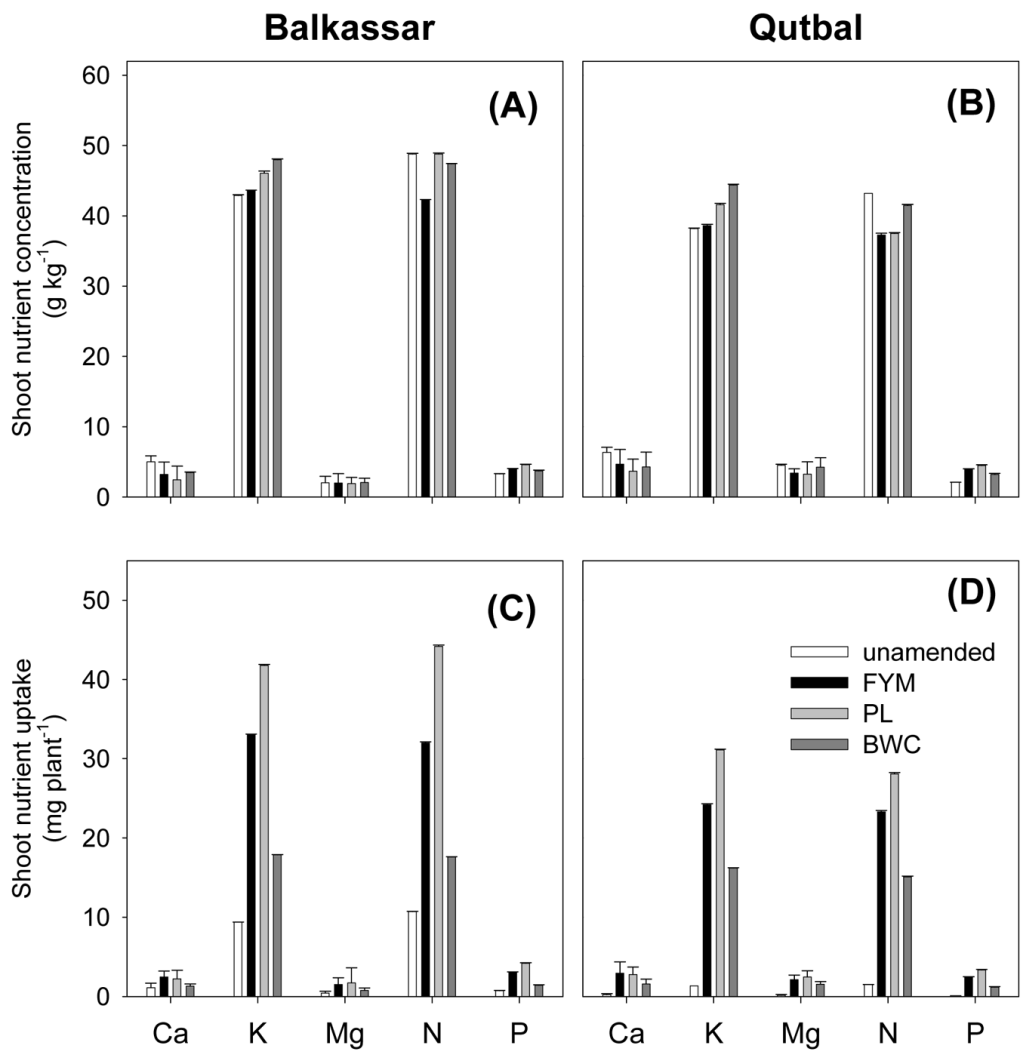

Figure 3. Shoot nutrient concentration (A, B) and shoot nutrient uptake (C, D) of wheat grown for 72 days Balkassar $(\mathrm{A}, \mathrm{C})$ and Qutbal soil (B, D) unamended or amended with farmyard manure (FYM), poultry litter (PL) or biogenic waste compost $(\mathrm{BWC})(\mathrm{n}=4$, vertical lines show standard deviation of data).

This makes BWC a longer lasting organic amendment compared to PL and FYM, but its nutrient release is quite low which limits its use fulness as nutrient source for rapidly growing plants such as wheat. The low available $\mathrm{P}$ concentrations indicate that net $\mathrm{P}$ release from BWC was low. The high shoot $\mathrm{K}$ concentration in the plants supplied with BWC can be explained by the high $\mathrm{K}$ concentrations in the compost. However, this did not result in higher $\mathrm{K}$ uptake than in the other organic amendments because of the smaller increase in plant growth by BWC compared to FYM and PL.
The effects of the organic amendments on plant growth and nutrient uptake were greater in Qutbal than in Balkassar soil which can be explained by the lower nutrient concentrations in the former. Thus although plant growth in the unamended soils was lower in Qutbal than Balkassar soil, shoot and root dry weight differed little between the two soils when amended. The higher clay and organic matter content of the Qutbal soil resulted in higher microbial biomass and activity thus favoured soil microbes making them more competitive than in the lighter textured Balkassar soil. 
Table 3. Wheat shoot and root dry weight and number of tillers in Balkassar and Qutbal soils unamended or amended with farm yard manure (FYM), poultry litter (PL) or biogenic waste compost (BWC) $(n=4)$.

\begin{tabular}{|c|c|c|c|c|}
\hline Soil & Treatment & $\begin{array}{c}\text { Dry shoot weight } \\
\left(\text { mg plant }^{-1}\right)\end{array}$ & $\begin{array}{c}\text { Dry root weight } \\
\text { (mg plant }^{-1} \text { ) }\end{array}$ & No. of tillers plant \\
\hline \multirow{4}{*}{ Balkassar } & Control & $220 \mathrm{E}$ & $79 \mathrm{D}$ & $1.0 \mathrm{D}$ \\
\hline & FYM & $760 \mathrm{~B}$ & $161 \mathrm{AB}$ & $3.3 \mathrm{AB}$ \\
\hline & PL & $910 \mathrm{~A}$ & $172 \mathrm{~A}$ & $3.8 \mathrm{~A}$ \\
\hline & BWC & $370 \mathrm{D}$ & $91 \mathrm{C}$ & $2.2 \mathrm{C}$ \\
\hline \multirow{5}{*}{ Qutbal } & Control & $40 \mathrm{~F}$ & $36 \mathrm{E}$ & $1.0 \mathrm{D}$ \\
\hline & FYM & $630 \mathrm{C}$ & $159 \mathrm{~B}$ & $2.8 \mathrm{~B}$ \\
\hline & PL & $750 \mathrm{~B}$ & $170 \mathrm{AB}$ & $3.3 \mathrm{AB}$ \\
\hline & BWC & $370 \mathrm{D}$ & $90 \mathrm{CD}$ & $1.8 \mathrm{C}$ \\
\hline & LSD & 75 & 12 & 0.5 \\
\hline
\end{tabular}

* Within columns, means followed by the same letter are not significantly different $(p \leq 0.05)$ by Tukey's HSD test.

On the other hand, the heavier texture of the Qutbal soil may have made it more difficult for the roots to penetrate than in lighter textured Balkassar soil. The higher clay content could also have resulted in anaerobic patches within the soil which would limit root growth.

\subsection{Temporal changes}

In the amended soils, the concentrations of $\mathrm{MBC}$, MBN and MBP as well as dehydrogenase activity decreased over time which indicates reduced microbial demand after the strong increase in these parameters immediately after addition of the amendments. Over time, the easily available compounds in the amendments (particularly PL and FYM) would be depleted resulting in the turnover of the microbial biomass. The increase in the $\mathrm{MBC} / \mathrm{MBN}$ and $\mathrm{MBC} / \mathrm{MBP}$ ratios indicate release of $\mathrm{N}$ and $\mathrm{P}$ which coincided with an increase in available $\mathrm{P}$ during this time. After day 28 , the $\mathrm{MBC}$ concentration increased, the MBN concentration remained stable and the MBP concentration increased in soils amended with FYM and PL. This indicates increasing $\mathrm{P}$ uptake by the microbes in this phase which was also apparent in the lower P availability. The increase in MBC concentration in this phase is some what surprising because the available $\mathrm{C}$ in the amendments is likely to be depleted in the first 28 days as evidenced by the decrease in MBC concentration. 
However after day 28 the plant roots and their exudates would have supplied the microbes with a relatively easily available C source (Akmal et al., 2004) which also resulted in a smaller decrease in dehydrogenase activity in the second phase. Nevertheless, microbial biomass $\mathrm{N}$ and $\mathrm{P}$ concentrations were lower on day 72 compared to day 0 indicating turnover of the microbial biomass which could release nutrients for plant uptake. This seems to contradict the decrease in P availability over time. However, plant nutrient uptake would also increase as plants grow and the larger root system would be able to deplete available P more strongly over time.

\section{Conclusions}

This study showed that organic amendments, particularly those with high nutrient concentrations, can stimulate microbial activity and growth as well as plant growth and nutrient uptake. Thus although there probably was some competition for nutrients between plants and microbes initially, microbial biomass turnover and nutrient mineralisation were sufficient to meet the demand of plants. The competitiveness of the plants may increase over time due to a larger root system which would allow uptake of nutrients released by microbial biomass turnover.

\section{Acknowledgments}

Muhammad Asghar Malik is deeply grateful to the Higher Education Commission, Islamabad, Pakistan for providing financial assistance to carry out this study.

\section{References}

Akmal, M., Khan K.S., Xu, J.M. 2004. Dynamics of microbial biomass in a rain-fed soil under wheat cultivation. Pedosphere. 14, 53-62.
Alef, K. 1995. Dehydrogenase activity. In: K. Alef, P. Nannipieri, (eds).Methods in Applied Soil Microbiology and Biochemistry. Academic Press Inc, San Diego, Ca, pp: 228-230.

Anderson, J.M., Ingram, J.S.I. 1993. Tropical Soil Biology and Fertility. CAB International, Wallingford, UK.

Ayaga, G., Todd, A., Brookes, P.C. 2006. Enhanced biological cycling of phosphorus increases its availability to crops in low-input sub-Saharan farming systems. Soil Biol. Biochem. 38, 81-90.

Brookes, P.C., Powlson, D.S., Jenkinson, D.S. 1982. Measurement of microbial biomass phosphorus in soil. Soil Biol.Biochem. 14, 319-329.

Brookes, P.C., Landman, A., Pruden, G., Jenkinson, D. S. 1985. Chloroform fumigation and the release of soil nitrogen: a rapid direct extraction method for measuringmicrobial biomass nitrogen in soil. Soil Biol. Biochem. 17, 837-842.

Chrzanowski, T.H., Kyle, M. 1996. Ratios of carbon, nitrogen and phosphorus in Pseudornonas fluorescens as a model for bacterial element ratios and nutrient regeneration. Aquat. Microb.Ecol. $10,115-122$.

Docampo, R., Ulrich, P., Moreno, S.N.J. 2010. Evolution of acidocalcisomes and their role in polyphosphate storage and osmoregulation in eukaryotic microbes. Phil. Trans. R. Soc. 365, 775-784.

Gee, G.W., Bauder, J.W. 1986. Particle size analysis. In: A. Klute (ed).M Agronpmy No.9, Madison, WI, pp: 383-411.

Gichangi, E.M., Mnkeni, P.N.S., Brooks, P.C. 2009. Effects of goat manure and inorganic phosphate addition on soil inorganic and microbial biomass phosphorus fractions under laboratory incubation conditions. Soil Sci. Plant Nutr. 55, 764-771. 
Joergensen, R.G., Kubler, H., Meyer, B., Wolters, V. 1995. Microbial biomass phosphorus in soils of beech (Fagussylvatica L.) forests. Biol. Fert. Soils. 19, 215-219.

Khan, K.S., Joergensen, R.G. 2009. Changes in microbial biomass and $\mathrm{P}$ fractions in biogenic household waste compost amended with inorganic P fertilizers. Bioresour. Technol. 100, 303-309.

Khan, K.S., Joergensen, R.G. 2006. Microbial C,N, and $\mathrm{P}$ relationships in moisture-stressed soils of Potohar, Pakistan. Plant Nutr. Soil Sci. 169, 494500 .

Malik, M.A., Khan, K.S., Marschner, P., Ali, S. 2012. Organic amendments differ in their effect on microbial biomass and activity and on P pools in alkaline soils. Biol.Fertil. Soils.DOI10.1007/s00374-012-0738-6.

Muhammad, S., Müller, T., Joergensen, R.G. 2008. Relationships between soil biological and other soil properties in saline and alkaline arable soils fromthe Pakistani Punjab.Arid Environ. 72, 448-457.

Murphy, J., Riley, J.P. 1962. A modified single solution method for the determination of phosphate in natural waters.Anal.Chem. Acta. 27, 31-36.

Nelson, D.W., Sommers, L.E. 1982. Total carbon, organic carbon and organic matter. In: A.L. Page, R. H. Miller, D. R. Keeney (eds). Methods of Soil Analysis. Part 2: Chemical and microbiological properties.American Society of Agronomy, Madison, WI, pp: 539-579.

Olsen, S.R., Sommers, L.E. 1982. Phosphorus. In: A.L. Page (ed). Methods of soil analysis, Agron No.9, Part 2: Chemical and microbiological properties, Second Edition.American Society of Agronomy, Madison, WI, pp: 403-430.
Peters, J., Combs, S., Hoskins, B., Jarman, J., Kovar, J., Watson, M., Wolf, A., Wolf, N.2003. Recommended methods for manure analysis. Madison, WI, USA.

Reddy, D.D., Rao, S.A., Singh, M. 2005. Changes in P fractions and sorption in an Alfisol following crop residues application. J. Plant Nutr. Soil Sci. 168, 241-247.

Ryan, J., Estefan, G., Rashid, A. 2001. Soil and plant analysis laboratory manual.2n.ed. Aleppo, Syrian Arab Republic ICARDA.

Ryazanova, L.P., Suzina, N.E., Kulakovskaya, T.V., Kulaev, I.S. 2009. Phosphate accumulation of Acetobacterxylinum. Arch. Microbiol. 191, 467-471.

Singh, B.B., Jones, J.P. 1976. Phosphorus sorption and desorption characteristics as affected by organic residues. Soil Sci. Soc. Am. J. 40, 389-394.

Takeda, M., Nakamoto, T., Miyazawa, K., Murayama, T., Okada, H. 2009. Phosphorus availability and soil biological activity in an Andosol under compost application and wintercover cropping. Appl. Soil Ecol. 42, 86-95.

Vance, E.D., Brookes, P.C., Jenkinson, D.S. 1987. An extraction method for measuring soil microbial biomass C. Soil Biol. Biochem. 19, 703-707.

Wang, F.E., Chen, Y.X., Tian, G.M., Kumar, S., He, Y.F., Fu, Q.L., Lin, Q. 2004. Microbial biomass carbon, nitrogen and phosphorus in the soil profiles of different vegetation covers established for soil rehabilitation in a red soil region of southeastern China. Nutr. Cycl.Agroecosys. 68, 181189.

Wu, J., Joergensen, R.G., Pommerening, B., Chaussod, R., Brookes, P.C.1990. Measurement of soil microbial biomass $\mathrm{C}$ by fumigation-extraction an automated procedure. Soil Biol. Biochem. 22, 1167-1169. 